\title{
Okul Öncesi Eğitim Çağında Çocuğu Olan Ebeveynlerin Değerler Eğitimi Hakkındaki Görüşlerinin İncelenmesi ${ }^{1}$
}

\author{
DOI: $10.26466 /$ opus. 864098
}

$*$

\author{
Ensar Y1ld1z * - Hasibe Elibol ** - Merve Ada *** \\ * Araştırma Görevlisi, Sivas Cumhuriyet Üniversitesi, Eğitim Fakültesi, Sivas/Türkiye \\ E-Posta: ensaryildiz@outlook.com.tr ORCID: 0000-0003-3741-1121 \\ ** Okul Öncesi Öğretmeni, Milli Eğitim Bakanlığı, Sivas/Türkiye \\ E-Posta: hasibe.elibol@gmail.com \\ ORCID: 0000-0003-4965-784X \\ ***Yl. Öğr.,Sivas Cumhuriyet Üniversitesi, Eğitim Fakültesi, Sivas/Türkiye \\ E-Posta: merveada14@gmail.com \\ ORCID: 0000-0001-9313-2456
}

Öz

Bu çalışmada, okul öncesi eğitim çağında çocuğu olan ebeveynlerin değerler eğitimi hakkındaki görüşlerinin belirlenmesi amaçlanmıştır. Çalışmada nitel araştırma yöntemlerinden durum çalışması kullanılmıştır. Çalışma grubunu okul öncesi dönem çocuğu olan 17 ebeveyn oluşturmaktadır. Araştırmanın örneklem seçiminde amaçlı örneklem türlerinden ölçüt örnekleme kullanılmıştır. Çalışmada veri toplamak için nitel araştırma tekniklerinden görüşme tekniği kullanılmıştır. Çalışmada veri toplama aracı olarak, araştırmacılar tarafından oluşturulmuş olan yarı yapılandırılmış görüşme formu kullanılmıştır. Toplanan verilerin analizinde ise Maxqda Pro2018.2.5 programı aracıl ğ̆ıla betimsel ve içerik analizi yapılmıştır. Ebeveynlerin değer kavramıni; saygl, sevgi, kültür ve toplumsal kabuller olarak ifade ettiği bulgulanmıştır. Ebeveynlerin çocuklarına en çok öğretmek istedikleri değerler saygı, sevgi ve ahlaki değerler üzerinde yoğunlaşırken en az sabır değerinin kazandırmak istedikleri tespit edilmiştir. Ebeveynlerin aile içi ilişkilerinde değerleri vurgularken çocuklara iyi bir rol model olmaya çalıştıkları, bekledikleri değerlere ilişkin davranışları sergiledikleri bulgulanmıştır. Araştırma sonuçlarını incelediğimizde; çocukların değerleri öğrenmeleri için resimli öykü kitapları okudukları sonucuna ulaşılmıştır. Ebeveynler değerler öğretimine iliş̧in okullardan beklentileri incelendiğinde; öğretmenin rol model olmasın, evdeki değerlerin pekiştirilmesini ve çocukların sosyalleşmesini sağlamak olduğu sonucuna ulaşılmıştır. Ayrıca ebeveynlerin çocuklarına en çok paylaşama değerini kazandırmakta zorluk yaşadıkları sonucuna ulaşılmıştır.

Anahtar Kelimeler: Değerler eğitimi, değer kavramı, ebeveyn görüşü, okul öncesi dönem

\footnotetext{
${ }^{1}$ Bu çalışma 24-26 Aralık 2020 tarihinde Karabük'te gerçekleştirilen 4. Uluslaraası Eğitim ve Değerler Sempozyumu (Online)'nda sözlü bildiri olarak sunulmuştur.
} 


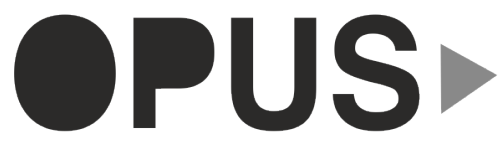

Uluslararası Toplum Araştırmaları Dergisi International Journal of Society Researches
E-ISSN : 2528-9535

YIl Year: 11

Cilt Volume: 18

Sayı Issue :40

Ağustos August 2021

Makalenin Geliş Tarihi Received Date: 19/01/2021

Makalenin Kabul Tarihi Accepted Date: 01/03/2021

\title{
Examination of the Views of the Parents that Preschool Children on Values Education
}

\begin{abstract}
This study aims at determining the views of the parents, who have kids in preschool period, on values education. Case study, one of the qualitative research methods, was used in the study. The study group consists of 17 parents who have kids at preschool age. Criterion sampling, among non-probabilistic methods, is used for the selection of samples in the research. The interview method which is one of the qualitative research methods was used for data collection. In the study, a semi-structured interview form that was prepared by the researchers was used as data collection tool. Descriptive analysis and content analysis have been utilized for the statistical analysis of the obtained data via Maxqda Pro2018.2.5 software. It was found out that the concept of values of parents were revealed as respect, love, culture and social acceptances. It was detected that parents focus on gaining their kids the values; respect, love and morality at most while they want to teach the value; patience at least. Reviewing the results of the research, it has been revealed that parents read picture storybooks to their kids so that they acquire the values. Furthermore, it was detected that parents have difficulty in teaching the value of sharing.
\end{abstract}

Keywords: Preschool period, value concept, values education, views of parents 


\section{Giriş}

Erken çocukluk dönemi çocuğun çevresiyle karşılıklı ilişkiler kurmaya istekli olduğu, çevreyi araştırarak tanımaya başladığı ayrıca içinde bulunduğu toplumun değerlerini ve kültür yapısını öğrenip uygun davranış ve ilişkiler geliştirdiği bir dönem olarak insan yaşamında önemli bir yer tutmaktadır (Demiriz, Ulutaş ve Karadağ, 2003). Erken çocukluk dönemi, çocukların ileride kazanacakları becerilerin temelinin atıldığı ve tüm gelişim alanlarında hızlı bir ilerleme gösterdiği bir dönem olduğundan, bu dönemde çocuklara sunulan uyarıcıların niteliğinin ve niceliğinin iyi olması oldukça önemlidir (Güven ve Azkeskin 2010; Şahin, 2010). Özellikle çocuğun kişilik yapısının, inanç, alışkanlık, tavır ve değer yargıların kazanılması açısından kritik olan bu dönemde çocukların, erken yaşlarda toplumun değerleri ile tanışmaları bu değerleri içselleştirip karakter haline getirmelerini kolaylaştırmaktadır (Ada, 2016; Karaömerlioğlu, 2010; Tanrıverdi, 2012). Çünkü değerler çocuğun tüm yaşamını doğrudan etkilemektedir (Ada, 2016). Değer, toplumda yaşayan insanlar tarafından doğru olduğu kabul edilen, değişimi uzun ve çok yönlü olan, bireylerden uymasını beklediği temel ilke veya inançlardır (Türk, 2009). Değerler konusuyla ilgili alanda yapılan çok çalışma olmasına rağmen henüz herkes tarafından kabul gören bir tanımı yapılamamıştır (Dilmaç, 2002). En genel anlamıyla değerler iyi veya kötünün ne olduğu hakkındaki yargılarımizdır (Veugelers ve Vedder, 2003).

Değerler toplumdaki değişmelerden etkilenmektedir. Dolayısıyla küreselleşmenin oldukça hızlı olduğu günümüzde toplumu ve toplumu oluşturan bireylerin sahip olduğu değerlerde de değişiklikler meydana gelmektedir. Değerlerini kaybetmeye başlamış bir toplumun sosyal kontrol gücünü yitirmesi ve zamanla hem kendi içinde hem diğer toplumlarla çatışmalar yaşaması kaçınılmaz olabilmektedir. Bu çatışmaların yaşanmaması için değerlerin korunarak nesilden nesile aktarılması gerekmektedir (Avcı, 2007; Gümüş, 2017). Bu açıdan bakıldığında toplum değerlerinin yeni nesle aktarılmasinda değerler eğitimi anahtar bir role sahiptir (Abacı, 2018).

Değerler eğitimi, toplumda yaşayan bireyleri birbirine bağlayan, onların huzurlu ve mutlu olmasını sağlayan, sosyal hayatı oluşturan, onları tehlikeli durumlardan koruyan tüm değerlerin bireylere aktarılıp kazandırılma sürecidir (Milli Eğitim Bakanlığ [MEB], 2010). Değer eğitimi sayesinde bireyler, yaşamlarında yol gösterecek bir dizi ilkeyi öğrenme olanağı bulmaktadır. 
Toplum onayını almış ilkelere göre, sosyal yaşamın şekillendirilmesi, bireylere var olan değerlerin aktarılması ve benimsetilmesi önemli görülmüştür. Dünyanın barış içerisinde yaşayan toplumlara sahip olması için, kültür öğesi olan değerlerin tüm insanlar tarafından benimsenmesi ve geliştirilmesi önemli bir olgu olarak kabul edilmektedir. Bunu gerçekleştirebilmenin en önemli yolu ise değerler eğitiminden geçmektedir. Değerler eğitimi, güzel bir hayat, huzurlu bir toplum ve daha barışçıl bir dünya için sağlam bir temel teşkil etmektedir (Türkkahraman, 2003). Çünkü değerler eğitimi olumsuzluklar ile başa çıkmada bir çıkış yolu olarak görülmektedir (Sapsağlam, 2016).

Değerler eğitiminin amacı, başta birey olmak üzere toplumu istenmeyen kötü ahlaktan korumak, toplumun devamlılı̆̆ını sağlamak, bireyin doğuştan var olan iyi taraflarını ortaya çıkararak, kişiliklerinin tüm yönleriyle gelişmesine yardım etmek, onların toplum tarafından kabul gören güzel ahlaka sahip bireyler olmalarını sağlamaktır (Aydın ve Akyol, 2012). Bu açıdan, değerler eğitimi insanlarda; sorumluluk, sayg1, yardımseverlik, vatanseverlik, dostluk, adalet gibi pek çok toplumsal ve bireysel değerleri kazandırmayı hedeflemektedir (Altan, 2011).

Son yıllarda dünyanın birçok ülkesinde değerler eğitimine verilen önemin arttığı görülmektedir. Bunun nedeni insanların, insanlığın ve toplumun temel değerlerinden koparak farklı arayış içine girmeleri ve değerlerden yoksun yaşamalarıdır. Bu durumun insanlığın ve toplumun geleceğini açıkça tehdit ettiği görülmektedir. Bu kötü gidişatı durdurmak ve hatta tersine çevirmek için Türkiye'nin de dâhil olduğu birçok ülke değerlerin ön plana çıtığı eğitim arayışı içine girmiş ve bunun sonucunda da değerler eğitimi her ülkenin eğitim programının vazgeçilmez bir unsur olarak yerini almaya başlamıştır (Ulusoy ve Arslan, 2014; Yaman, 2012)

Okullarda hem planl, programlı hem örtük bir şekilde verilen değerler eğitimiyle, bireylerin toplum değerlerini benimsemesi, karakter haline getirmesi ve geliştirmesi sağlanmaktadır (Güler, 2015). Formal eğitimin ilk basamağı olan okul öncesi eğitimde, çocuğun tüm gelişimsel özellikleri dikkate alınarak hazırlanan programda değerler eğitimi önemli bir yer tutmaktadır (Samur, 2011). Okul öncesinde verilecek değerler eğitiminin kapsamı bireysel, ahlaki ve toplumsal değerleri içermeli, ayrıca çocukların gelişim özelliklerine uygun olarak ayrı ayrı değil bir bütün olarak ele alınmalıdır (Dinç, 2011). Bu açıdan iyi bir okul öncesi eğitim programı, çocuğun bilişsel becerilerini geliştirmenin yanında, sosyal ve duygusal gelişimini de dikkate alarak, 
evrensel değerleri tüm çocuklara aktararak toplumun devamlılığını sağlamalıdır (Greenberg vd, 2003).

Çocuğun doğduğunda karşılaştı̆̆ ilk toplumsal grubun aile olması, değerler eğitiminde ailenin yerinin ne kadar önemli olduğunu bir kez daha ortaya çıkarmıştır (Kır, 2010). Çocuğun toplum değerleriyle ilk karşılaştığı ve değerler eğitimini almaya başladığ1 yer ailesi olduğundan toplumun değer yargılarına uygun yetişmesinde aile oldukça önemli bir yere sahiptir (Çağdaş ve Seçer, 2002). Çocuklar kişiliklerini şekillendiren toplum değerlerini, kurallarını ve kültürünü ailedeki bireylerle etkileşime girerek, özellikle de anne babasın gözlemleyerek, onları model alarak öğrenmektedir (Balat ve Balaban, 2011; Günindi, 2010). Ayrıca aile kendi tutumları ile toplumsal değerleri bireye aktararak onun toplumun bir parçası olmasına yardımcı olmaya çalışmaktadır (Şahin, 2005).

Sonuç olarak; kişilik gelişimini tamamlamış, toplumun değer yargılarına sahip bireyler yetiştirmek toplumun, okulun ve ailenin en önemli görevi olarak görülmektedir (Ekşi, 2003). Ailelerinin değerler eğitiminde önemli bir rol üstlenmesine rağmen alan yazın incelendiğinde ailelerle değerler eğitimine yönelik sınırlı sayıda çalışmaya rastlanmaktadır. Bu bağlamda çalışmanın önemli bir eksikliği gidereceği düşünülmektedir. Bu çalışmada okul öncesi eğitim çağında çocuğu olan ebeveynlerin değerler eğitimi hakkındaki görüşlerinin incelenmesi amaçlanmaktadır. Bu amaç doğrultuda aşağıdaki sorulara yanit aranmiştır.

1. Ebeveynlere göre değer kavramı nedir?

2. Ebeveynlere göre en önemli değerler hangileridir?

3. Ebeveynlere göre değerler eğitiminde birinci derecede sorumluluk kime aittir?

4. Ebeveynlerin çocuklarına kazandırmak istedikleri değerler nelerdir?

5. Ebeveynlere göre değerleri kazanmanın çocuklara katkıları nelerdir?

6. Ebeveynlerin çocuklarına değer kazandırmak için izlediği yollar nelerdir?

7. Ebeveynlerin çocuklarına kazandırmakta zorlandıkları değerler nelerdir?

8. Ebeveynlerin, çocukların değerleri kazanıp kazanmadıklarını tespit etme yolları nelerdir?

9. Ebeveynlerin çocuklara değer kazandırmaya yönelik okul öncesi öğretmenlerinden beklentileri nelerdir? 
10. Ebeveynlere göre okul öncesi eğitim kurumlarındaki değer eğitimi çalışmalarının yeterliliği hakkındaki düşünceleri nelerdir?

\section{Yöntem}

Araştırmaya başlamadan önce, Sivas Cumhuriyet Üniversitesi Bilimsel Araştırma ve Yayın Etiği Sosyal ve Beşeri Bilimler Etik Kurulu Başkanlığı'nın 30.12.2020 tarihli ve E-60263016-050.06.04-499448 sayı numarası ile izin alınmiştır.

Çalışmada nitel araştırma yöntemlerinden durum çalışması kullanılmıştır. Durum çalışmaları, araştırmacının kontrol edemediği bir durum veya olayı, nasıl ve niçin sorularını temel alarak derinlemesine incelemeye olanak sağlayan bir yöntemdir (Yıldırım ve Şimşek, 2016).

\section{Çalışma Grubu}

Çalışma grubu oluştururken amaçlı örnekleme türlerinden ölçüt örnekleme kullanılmıştır. Ölçüt örnekleme, önceden belirlenmiş bir dizi kriterin çalışılmasını sağlamaktadır (Yıldırım ve Şimşek, 2016). Ölçüt olarak 3-6 yaş arasinda çocuğu olan ve bir okul öncesi eğitim kurumundan yararlanan ebeveynler seçilmiştir. Tablo 1'de ebeveynlere ait demografik bilgiler yer almaktadir.

Tablo 1. Çalş̧maya Katılan, 3-6 Yaş Grubu Çocuğu Olan Ebeveynlere İlişkin Demografik Bilgiler

\begin{tabular}{|c|c|c|c|c|c|c|}
\hline Katılımc1 & Yaş & $\begin{array}{l}\text { Eğitim } \\
\text { Düzeyi }\end{array}$ & $\begin{array}{l}\text { Çocuk } \\
\text { Sayısı }\end{array}$ & $\begin{array}{l}\text { Çocukların } \\
\text { Yaşlanı }\end{array}$ & Meslek & ìl/İlçe \\
\hline E1 & 34 & Ortaokul & 3 & $4,14,18$ & Ev hanımı & Antalya/Kepez \\
\hline E2(E) & 37 & Lisans & 2 & 2,5 ve 4,5 & Öğretmen & Sivas/Zara \\
\hline E3 & 28 & Lise & 1 & 4,5 & Ev hanımı & $\begin{array}{l}\text { İstanbul/Sultan- } \\
\text { beyli }\end{array}$ \\
\hline E4 & 34 & Lisans & 2 & 1 ve 5 & Öğretmen & Erzincan/Merkez \\
\hline E5 & 43 & Lisans & 2 & 6 ve 9 & Ev hanımı & Yozgat/Merkez \\
\hline E6 & 32 & Y. Lisans & 2 & 3 ve 6 & Öğretmen & Amasya/Merzifon \\
\hline E7 & 38 & Lisans & 2 & 4,5 ve 9 & Öğretmen & $\begin{array}{l}\text { İstanbul/Sancak- } \\
\text { tepe }\end{array}$ \\
\hline E8 & 30 & Ön lis. & 2 & 2 ve 4 & Eksper & Sivas/Merkez \\
\hline E9(E) & 31 & Lisans & 2 & 3 ve 5,5 & Polis & Mardin/Artuklu \\
\hline E10 & 29 & Lisans & 2 & 1,5 ve 3 & Ev hanımı & Kayseri/Merkez \\
\hline
\end{tabular}




\begin{tabular}{lllllll} 
E11 & 33 & Lise & 2 & 6 ve 8 & Ev hanımı & Sivas/Merkez \\
E12 & 26 & Lisans & 1 & 4 & Öğretmen & Kayseri/Merkez \\
E13(E) & 34 & Lisans & 1 & 4 & Öğretmen & Bursa/Ylldırım \\
E14 & 33 & Lisans & 2 & 1 ve 5 & Öğretmen & Tokat/Turhal \\
E15 & 32 & Lisans & 1 & 4 & Ev hanımı & Sivas/Ulaş \\
E16 & 27 & Lisans & 2 & 2 ve 3 & Öğretmen & K.maraş/Merkez \\
E17 & 37 & Lisans & 2 & 5 ve 11 & Öğretmen & Tokat/Merkez \\
\hline
\end{tabular}

Tablo 1 incelendiğinde katılımcıların 14'ünün kadın, 3'ün erkek olduğu görülmektedir. Katılımcılar 26 ve 43 yaş aralığında yer almaktadır.

\section{Veri Toplama Araçları}

Araştırmacılar tarafından geliştirilmiş olan "Kişisel Bilgi Formu" ve "Ebeveynlerin Değer Eğitimi Hakkındaki Görüşlerinin Belirlenmesine İlişkin Yarı Yapılandırılmış Görüşme Formu" kullanılmıştır.

Kişisel Bilgi Formu: Araştırmacılar tarafından geliştirilmiştir. Formda ebeveynlere yönelik olarak; ebeveynin yaşı, ebeveynin eğitim durumu, mesleği, çocuk sayısı, çocuk/ların yaşı, ailenin toplam gelir durumunu, ikamet edilen yer sorularına cevap aranmıştır.

\section{Ebeveynlerin Değer Eğitimi Hakkındaki Görüşlerinin Belirlenmesine İlişkin} Yarı Yapılandırılmış Görüşme Formu: Araştırmacılar tarafından ilk önce on sorudan oluşturulmuş daha sonra uzman görüşleri doğrultusunda on iki soru olarak hazırlanmıştır. Görüşme formunda; ebeveynlere göre en önemi değerler, ebeveynlerin değerler eğitiminde okuldan beklentileri, ebeveynler evde değerler eğitimini çocuklara hangi yollar ile verdikleri gibi sorular yer almaktadır. Geçerlik ve güvenirliği sağlamak açısından Lincoln ve Guba'nın (1986); inandırıcılık, aktarılabilirlik, tutarlılık ve teyit edilebilirlik aşamalarına uyulmuştur. İnandırıcılık aşaması için, hazırlanan form okul öncesi eğitim alanında değerler eğitimi ile ilgili çalışmaları olan üç uzmana gönderilmiştir. Uzmanlardan gelen dönütler sonrasında "Çocuğunuzun verilen değeri kazanıp kazanmadığını nasıl tespit ediyorsunuz?"; "Çocuğunuza herhangi bir değeri kazandırmaya çalışırken izlediğiniz yollar nelerdir?" soruları eklenerek soru sayısı on ikiye çıkarılmıştır. Sonrasında soruların anlaşılabilir olup ol- 
madığını ve soruların işlerliğini anlamak için üç ebeveyn ile görüşmeler yapılmıştır. Yapılan görüşmeler, soruların anlaşılırlığını ve yanıtların soruların cevabını içerip içermediği hem araştırmacılar hem de bir alan uzmanı tarafından incelenmiştir. Soruların istenilen verileri sağladığı kanısına varıldıktan sonra esas uygulamaya geçilmiştir. Yapılan görüşmelerde tüm katılımc1lara aynı sorular aynı sıra ile sorulmuştur. Sorular, açık ve anlaşılır sorulardır (Corbetta, 2003). Görüşme, önceden belirlenmiş bir amaç doğrultusunda soru sorma-yanıtlamaya dayalı düşünce, tutum ve deneyim gibi gözlenemeyen durumları belirlemeyi sağlayan karşlıklı etkileşim sürecidir (Yıldırım ve Şimşek, 2016). Görüşme formunun uygulama süresi yaklaşık 15-20 dakikadır. Görüşmeler pandemi süreci dolayısıyla yüz yüze yapılmayıp sesli ve görüntülü araçlar ile uzaktan yapılmıştır. Tutarlılık aşaması için yapılan görüşmeler yazılı hale getirilip katılımclara iletilerek onayları alınmıştır. Aktarılabilirlik aşaması için literatür incelenmiş ve ilgili çalışmalardan alıntılar yapılmıştır. Teyit edilebilirlik aşaması için, veri toplama ve veri analizi sürecinde üç uzman görüşüne başvurulmuş ve araştırma sürecinde elde edilen veriler gerektiğinde tekrar incelenmek üzere “E1, E2... E17” şeklinde kodlanarak saklanmıştır.

\section{Verilerin Analizi}

Araştırmada toplanan veriler MAXQDA Pro2018.2.5 programı aracilığıyla nitel araştırma yöntemlerinden betimsel ve içerik analizi kullanılarak çözümlenmiştir. Araştırmanın kavramsal yapısının belirgin olduğu durumlarda kullanılmaktadır (Yıldırım ve Şimşek, 2016). Ayrıca, yazılı dokümanların incelenmesinde kodların ve kategorilerin oluşturulması için Mayring (2004) tarafından önerilen içerik analizi tekniği kullanılmıştır. Bu bağlamda tümevarımcı kategorileştirme yapmak için önce toplanan ses kayıtları önce yazılı hale getirilmiş, Maxqda Pro2018.2.5 programı ile kodlar belirlenmiş ve problem durumuna göre geliştirilen üst kategoriler ile birleştirilerek temalar görsel haritalar ile oluşturulmuştur. Betimsel analiz doğrultusunda oluşturulan modele ilişkin katılımcların doğrudan örnek alıntı cümlelerine yer verilmiştir. 


\section{Bulgular}

Bu bölümde ebeveynlerle yapılan görüşmelerden elde edilen bulgulara ve bulgulara ait şekil ve yorumlamalara yer verilmiştir. Şekiller, görüşme formunda yer alan soruların sıralaması dikkate alınarak yerleştirilmiştir.

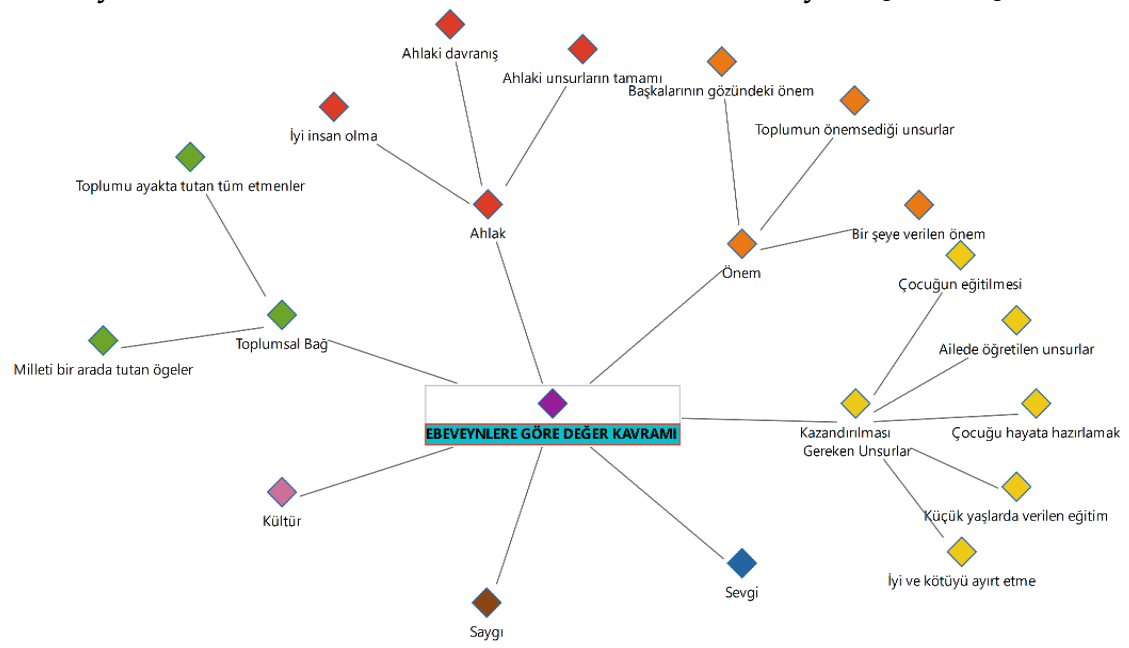

Şekil 1. Ebeveynlere Göre Değer Kavramı

Şekil 1'de ebeveynlere göre değer kavramı temasına ilişkin kodlar altı kategoride değerlendirilmiştir. Şekil detaylı incelendiğinde KGU içeriğine yönelik "Çocuğun eğitilmesi, ailede öğretilen unsurlar"; Öneme ilişkin "Toplumun önemsediği unsurlar, Bir şeye verilen önem, başkalarının gözündeki önem"; Ahlaka yönelik "Ahlaki unsurların tamamı, ahlaki davranış, iyi olma"; Toplumsal Bağ ile ilgili "Milleti bir arada tutan öğeler, Toplumu ayakta tutan etmenler" şeklindeki kodların oluştuğu görülmektedir. Ayrıca kültür, sevgi ve saygi İçeriğinde görüşlerin bu kavramlar üzerine birleştiği anlaşılmaktadır. Belirtilen kodlar katılımcı görüşlerine dayandırılarak oluşturuldu. Kodlarda referans alınan görüşlerden KGU'ya yönelik olarak E12 kodlu katılımcı "Şimdi değer kavramı ilk önce bizim çocuklara verdiğimiz eğitimi ifade eder. Yani Iıı... hayatı ilerde karşılaşacağı şeyler için her şey aslında. İnsancl davranışlar edinmekte diye biliriz. Onu hayata hazırlamak diye biliriz. Çocuklara vereceğimiz eğitimdir değer. İnsan olması için edindirdiğimiz her şey. Ya bunlar genel olarak." şeklinde görüşünü söylemiştir. Önem ile ilgili E14 kodlu katılımcı "Değer kavramı benim için aslında bir şeye 
derdiğimiz önem diyebilirim hocam. Bir şeye verdiğimiz önem, değer bunu derim." düşüncelerini dile getirirken, Ahlak için E3 katılımcı “Değer kavramı İnsanların ahlaki açıdan ailede çevrede yani ahlak göstermiş olduğu davranışlar." fikrini öne sürmüştür. Toplumsal Bağ için E16 kodlu katılımcı tarafından "Toplumu ayakta tutan etmenlerden birisi ya. Çocuklarımıza bıraktığımız miras. Yani herkesi bir arada oluşturan bir şey ya varlığımızın devamı. Aileyi oluşturan temel yapı taşları diyebiliriz." Şeklinde görüşünü belirtirken Kültürle ilgili E4 kodlu katılımc tarafından "Ne kavramı dediniz çok net duyamıyorum. Değer kavramı 111 işte insanın anne babasından çevresinden gördüğü onları normal olarak kabul ettiği 111 ve kültürün bir parçası olan şeylerdir diye düşünüyorum." diye görüş belirtmiştir. Saygı için E11 kodlu kattlımcı "Değerler kavramı bence bir çocuğa ne bileyim küçükken, küçük yaşlarda öğretilmesi gereken sevgi, sayg1, paylaşma 111 nasıl desem onlar yani. Nasıl davranması gerektiği yardımlaşma. O duyguların gelişmesi. Değer, sevgi, saygı, paylaşma onlar geliyor aklıma." düşüncesini söylerken sevgi ile ilgili olarak E13 kodlu katılımcı "Değer nedir biraz düşünelim. İnsanda bulunması gereken temel sevgi, saygı, iyilik kavramları yani genel olarak ilgi kavramları diye biliriz. Genel olarak bunu tanıtırım." şeklinde fikrini belirtmiştir. Bunun gibi diğer katılımcıların görüşleri de incelenerek Şekil 1'de sunulan modele ulaşılmıştır.

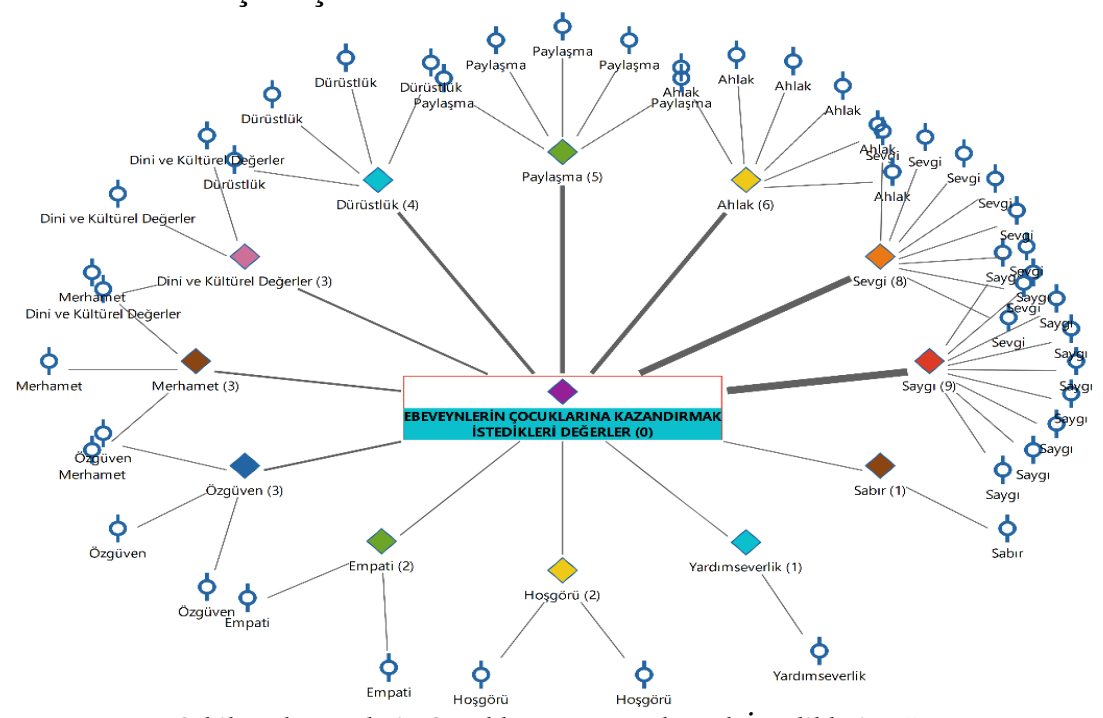

Şekil 2. Ebeveynlerin Çocuklarına Kazandırmak İstedikleri Değer 
Şekil 2' de ebeveynlerin çocuklara kazandırmak istedikleri değer temasına ilişkin kodlar on iki kategori oluşturulmuştur. Şekil detaylı incelendiğinde değerlerden en çok ifade edilen kodların "Saygı" daha sonra "Sevgi" ardından "Ahlak" olduğu, en az ise "Yardımseverlik" ve "Sabır" kategorinde olduğu anlaşılmaktadır. Saygı kategorisinin oluşmasına kaynaklık eden ifadelerden biri E13 kodlu katılımcının "Iı çocuğumuzun hangi değerleri kazanmasını isteriz. Sevgi, saygı, hoşgörü, inançlı biri olmasını isterim. Yani şuan aklıma bunlar geldi." şeklindeki düşüncesidir. Sabır kategorisinin belirlenmesine ilişkin referans alınan katılımcı görüşü ise E5 kodlu katılımcının "Iı1 çocuklarımın en çok sabrı öğrenmesini isterim..." şeklindeki düşüncesidir.

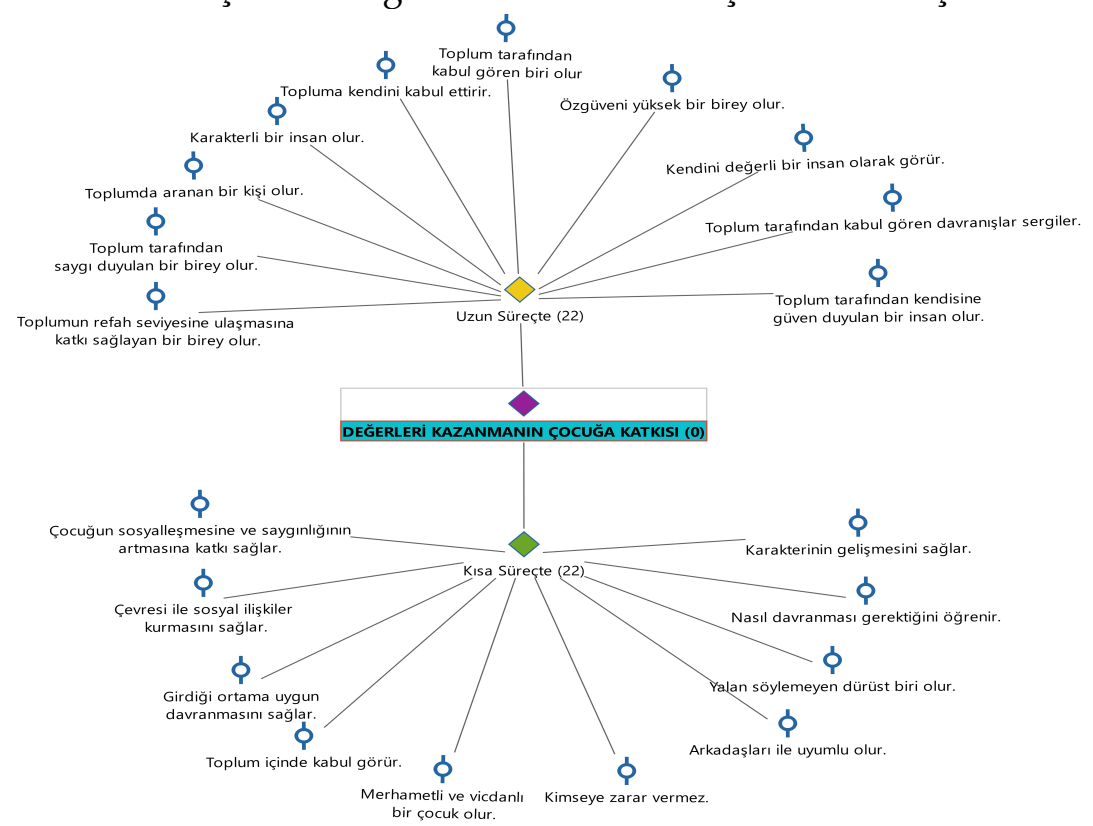

Şekil 3. Değerleri Kazanmanın Çocuklara Katkısı

Şekil 3 incelendiğinde değerleri kazanmanın çocuğa katkısı temasına ilişkin kodlar ile uzun süreçte ve kısa süreçte katkı kategorileri oluşturulmuştur. Uzun süreç kategorisinin oluşmasına kaynaklık eden örnek alıntı cümlesi içeriğine yönelik olarak E16 kodlu katılımcı "Uzun vadede ise hani toplumuna faydalı birey olur. Okulunda hani daha rahat olur. Çocuğum kendi kontrolünü nasıl desem hani toplum içinde daha rahat bir şekilde sağlar." diyerek fikrini belirtmiştir. Kısa süreç kategorisinin oluşturulmasına kaynaklık eden 
örnek alıntı E2 kodlu katılımcının "Eee kısa vadede çocuğun hayatını daha düzenli hale sokar. Yani insanlarla 111 sosyal olarak ilişkilerinde, aile ilişkilerinde, akraba ilişkilerinde, okul ilişkilerinde onlara daha uyumlu olmayı sağlar kısa vadede. Iı1ı gittiği yerlerde uyum sağlamayı, huzursuzluk çıkarmamayı ee insanlarla iyi ilişki kurmasını sağlar" şeklindeki düşüncesidir.

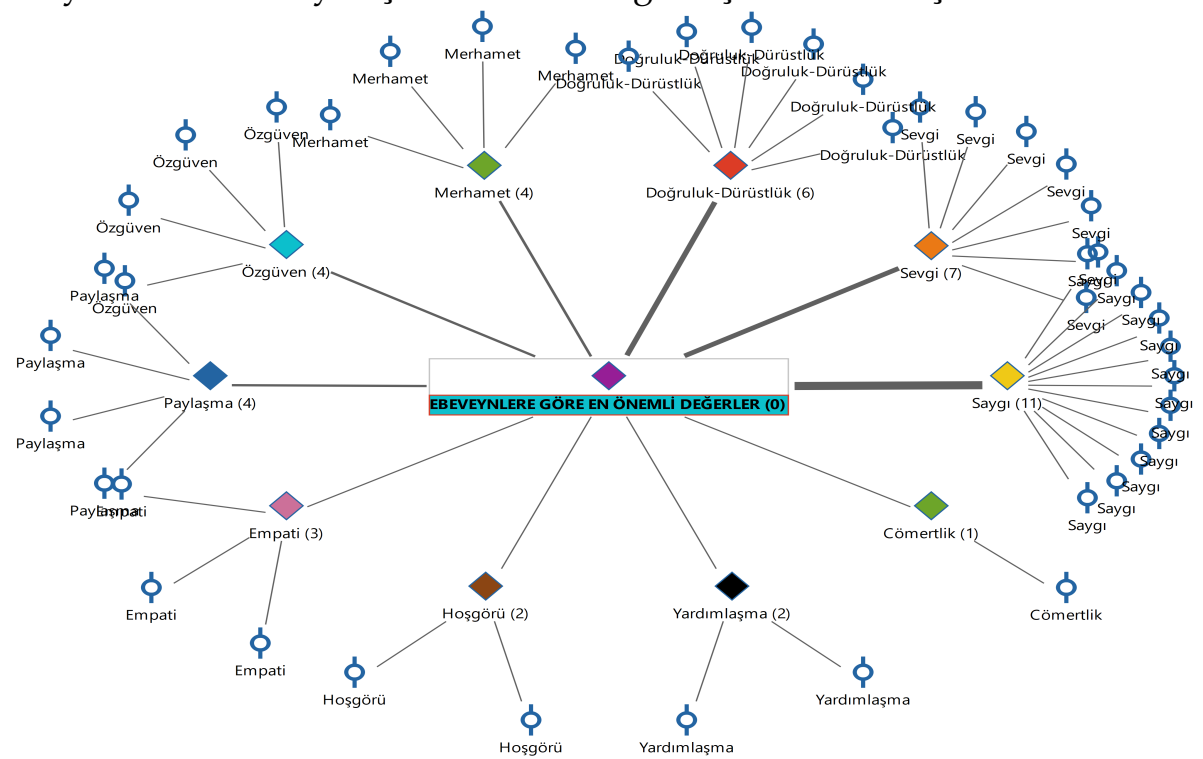

Şekil 4. Ebeveynlere Göre En Önemli Değerler

Şekil 4'te ebeveynlere göre en önemli değerler temasına ilişkin on kategori oluşturulmuştur. Kategorilerin oluşmasına referans olan örnek kodlar aşağıda yer almaktadır.

E17: “Doğruluk bence çok önemli. I11.. çünkü yalanın olduğu yerde güven olmuyor yani kendi bireysel olarak yaşantımızda da bu aynen bu şekilde Iı... kendimize ve karşımızdaki insana güvene bilmemiz için doğru söylediğinden, doğru yaptığından emin olmalıyız. Hata olabilir çocuklarda ve de bizlerde ama Iı1.. yalan söylemeyeceğini biliyorsak eğer daha güvenilir daha rahat bir hayat göreceğiz. Güven anlamında I11.. bence yalansız, doğru bir hayat, doğruluk çok önemli benim için."

E11 kodlu katılımcının "Sevgi, saygı, yardımlaşma, paylaşma onlar bence. Mesela bir tek kendini sevmesin herkesi sevsin mesela kardeşini, arkadaşlarını herkesi sevsin yani bencil olmasın diye. Saygılı olsun kendinden büyük- 
lere de yani paylaşsın her şeyini mesela oyuncaklarını falan. eee yardımcı olsun mesela tek kendi halinde yaşamasın etrafındaki kişilere de yardım etsin. Öyle."

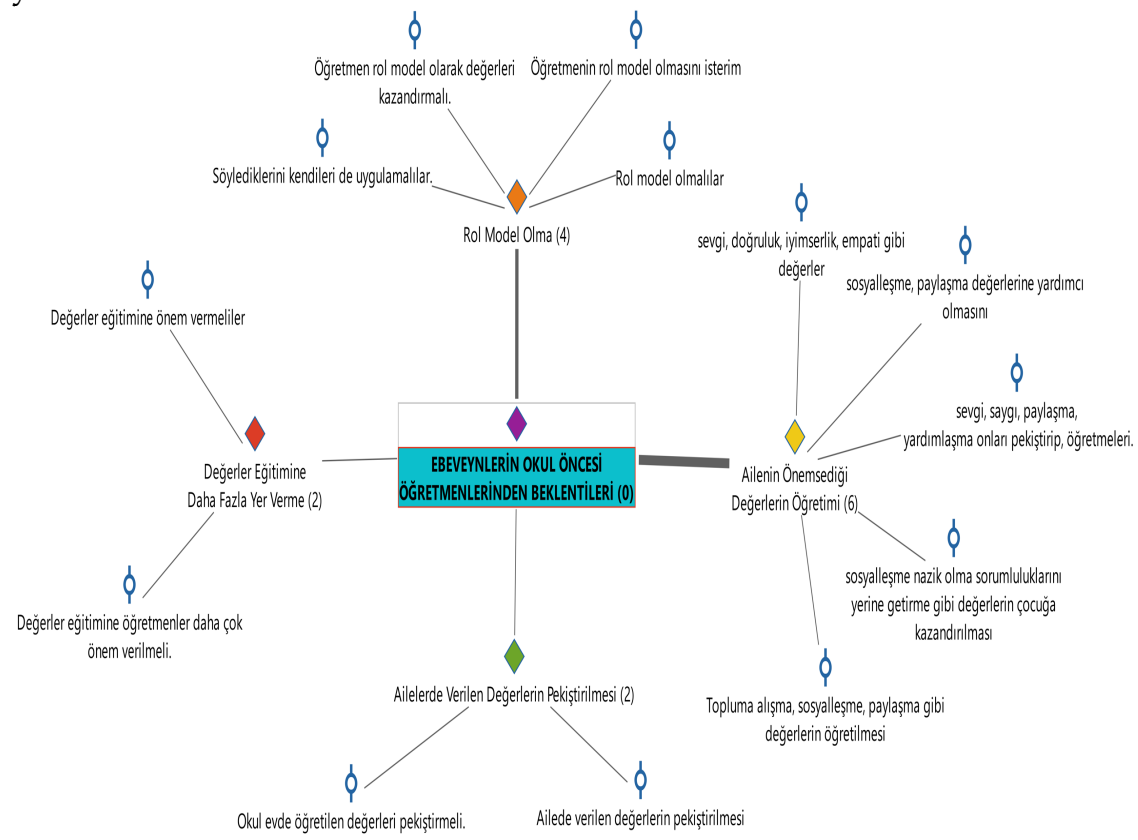

Şekil 5. Ebeveynlerin Okul Öncesi Öğretmenlerinden Beklentileri

Şekil 5'te yer alan ebeveynlerin okul öncesi öğretmenlerinden beklentileri temasına ilişkin "Ailelerin önemsediği değerlerin öğretimi, Rol model olma, Değer eğitimine daha fazla yer verme, Ailelerde verilen değerin pekiştirmesi" kategorileri oluşturulmuştur. Kategorilerin oluşmasına aracılık eden örnek alıntılardan E15 kodlu katılımcı “... fakat değer eğitiminin daha fazla okulda olmasını isterim." şeklinde düşüncesini ifade ederken; E5 kodlu katılımcı "Eee okuldan beklentilerimiz 111 çocuklarımıza verdiğimiz değerleri kendilerinin pekiştirmesi çünkü öğretmen çok önemli burada yani ...." şeklinde fikrini belirtmiştir. 


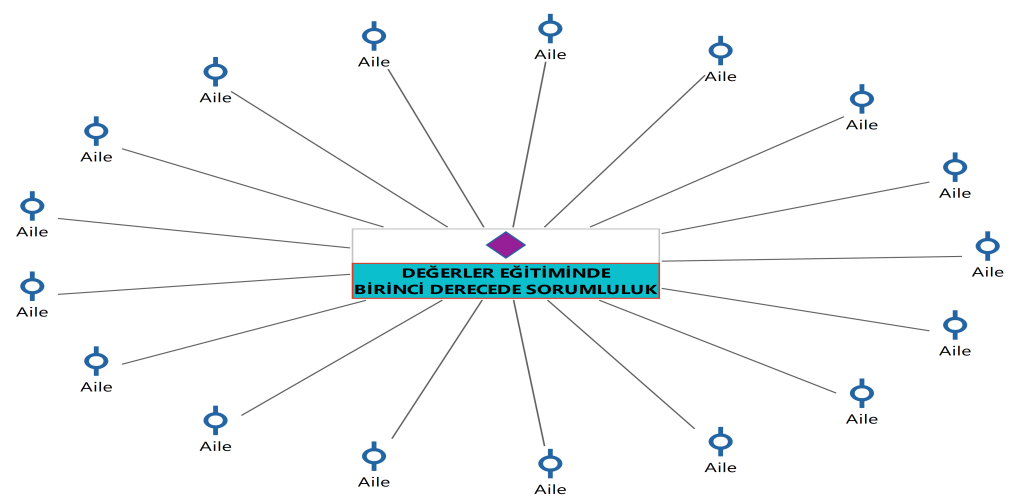

Şekil 6. Değerler Eğitiminde Birinci Derecede Sorumluluk

Şekil 6' da değerler eğitiminde birinci derece sorumluluk temasına ilişkin oluşturulan kodların "Aile" olduğu görülmektedir. İlgili kodlardaki ifadelerden biri E7 kodlu katılımcının "Toplumun en küçük parçası olarak önce aile bence. Ailede hani ailelerde birleşip toplumu oluşturduğuna göre bence kesinlikle aile. " ve E1 kodlu katılımcının "Ya bence ilk başta da söylediğim gibi bence ailedir. Bence aile." görüşüdür.

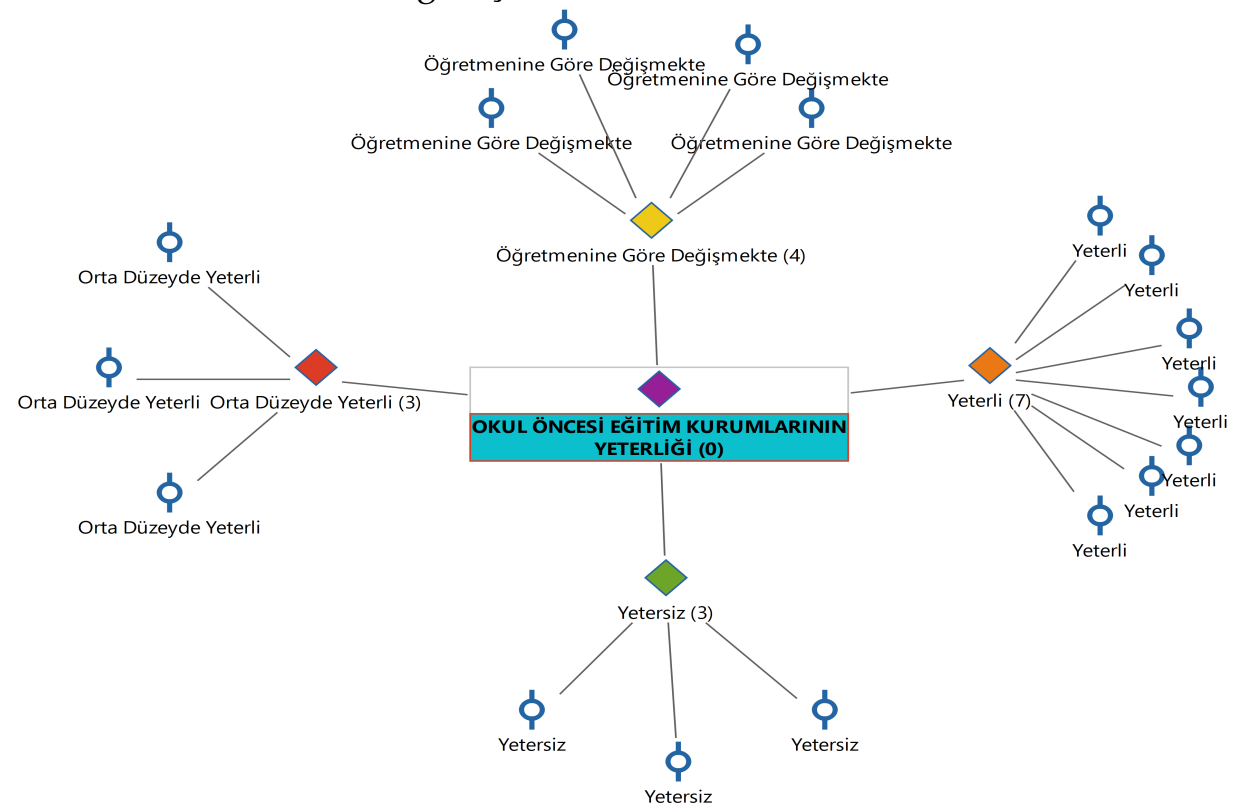

Şekil 7. Okul Öncesi Eğitim Kurumlarmnn Değerlerin Edinilmesine Yönelik Çalışmalarının Yeterliği 
Şekil 7 incelendiğinde okul öncesi eğitim kurumlarının değerlerin edinilmesine yönelik yeterliliği temasına ilişkin kodlar doğrultusunda "Yeterli, Öğretmene göre değişmekte, Orta düzeyde yeterli, Yetersiz" şeklinde kategoriler oluşturulmuştur. Bu kodlara referans gösterilecek ifadeler E16 kodlu kattlımcının "Okuldan aldıkları şey aslında yeterli değil. Hani buda bizlerden, velilerden, ailelerden kaynaklanıyor. Çocuklarının hep sadece derse yönelik çalışmalarını istiyor. Sosyal yönlerini hiç düşünmediklerinden dolayı yetersiz bence." ve E2 kodlu katılımcının "Yani burada iş tamamen okul yönetimine ya da işte o okuldaki öğretmene kalıyor. Gerçekten ee ben de öğretmen olduğum için öğretmen arkadaşlarımın yaptığı çalışmaların ee yeterli ve eee değerli olduğunu düşünüyorum. Çünkü çocuklara eee verilmesi gereken kazanımları, sorumlulukları, değerleri verdiklerini düşünüyorum. Yani okul öncesi eğitimin çok faydalı olduğunu düşünüyorum ve bu okul öncesi eğitimde bütün çocukların ee okul öncesi eğitim almaları gerektiğini düşünüyorum. Veriyorlar evet okul öncesi eğitimde bu değerler yani gerçekten iyi veriliyor. Okul öncesi eee öğretmen arkadaşlarım işlerini yapıyorlar. Bu değerleri veriyorlar diye düşünüyorum." şeklinde ifadeleridir.

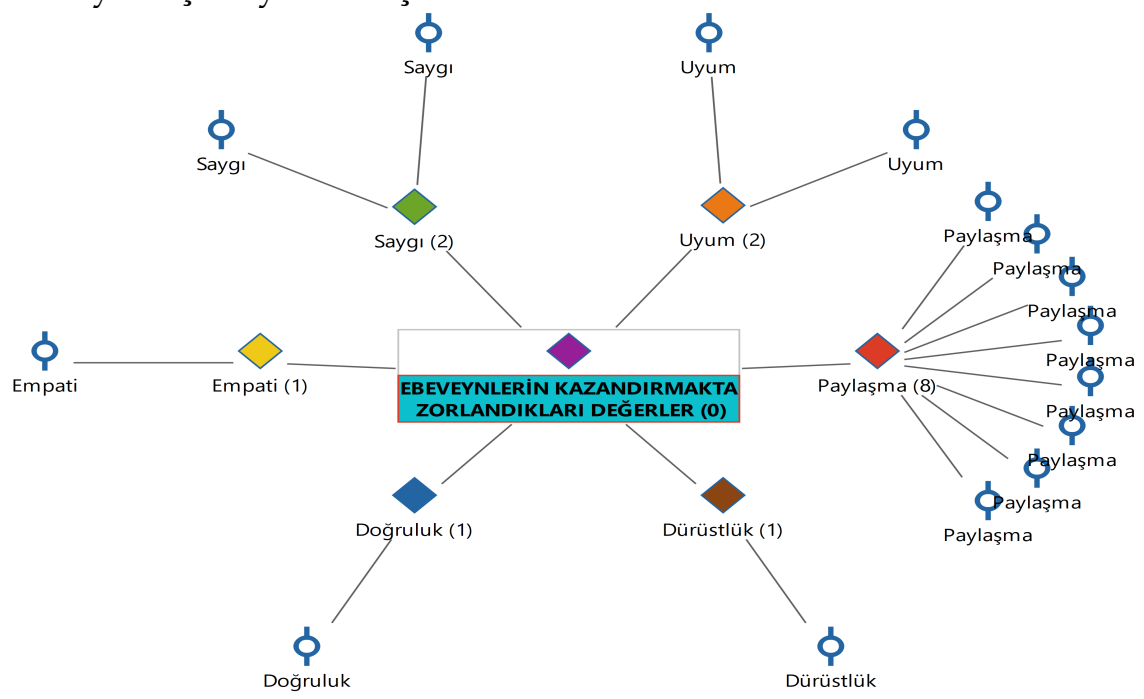

Şekil 8. Ebeveynlerin Çocuklarına Kazandırmakta Zorlandıklan Değerler

Şekil 8'de ebeveynlerin kazandırmakta zorlandığı değerler temasına yönelik kodlar "Paylaşma, Dürüstlük, Saygı, Empati, Doğruluk, Dürüstlük" kategorilerinde değerlendirilmiştir. Kategorilerin oluşmasına kaynaklık eden 
kodlarla ilgili örnek alıntı ifadeler, E8 kodlu katılımcı "Paylaşım evet çok zorlanıyorum. Benim kızım paylaşmak istemiyor, oyuncağını paylaşmak istemiyor, kıyafetlerini paylaşma bir tokasını yani kardeşinden bahsediyorum yani çok bir arkadaşı yok paylaşmak sıfır yani hiç yok bu kazanımı mesela dediğim gibi okulda öğretmenler bunu daha iyi yapabileceğini düşünüyorum." şeklinde söylerken E15 kodlu katılımcr "Hangi değerleri mesela doğru söylemede biraz zorlanıyoruz. Mesela I11.. tepki vermemek istiyoruz yalan söylediği zaman. Acaba tepkimden mi korkuyor diye şey yapıyorum ama bu yaştaki çocuklar 5 yaşında benim oğlum çok kolay rahat yalan söyleyebiliyor ama oyunla şey hani hayal dünyası arasında kaldıkları için diyorlar ya gerçekle hayal dünyası arasında bunu birazcık yorumluyorum. Ama ilerleyen zamanlarda tabi bu israrla böyle yalan söylememe, zararlı olduğunu en çok kendisine zarar vereceğini söyleye söyleye ve bunu yaşaya yaşaya bizimle öğreneceğini düşünüyorum. En çokta o konuda biraz zorlanıyoruz. Şuan için." şeklinde görüşünü belirtmiştir.

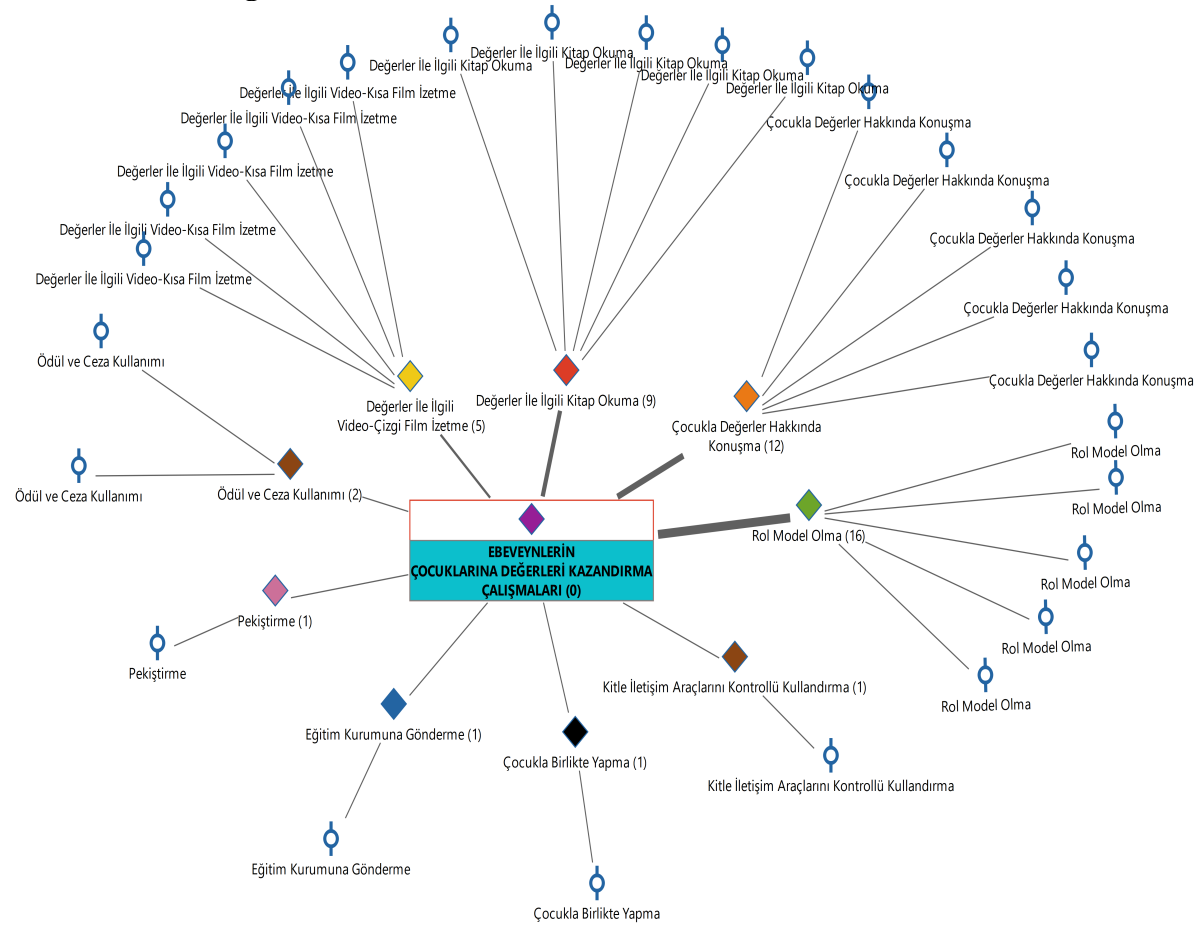

Şekil 9. Ebeveynlerin Çocuklara Değerleri Kazandırtrken İzlediği Yollar 
Şekil 9 incelendiğinde ebeveynlerin çocuklara değerleri kazandırma çalışmaları temasına yönelik kodlar "Rol model olma, Değerler ile ilgili kitap okuma, Kitle iletişim araçlarını kontrollü kullanma, Ödül ve ceza kullanımı " şeklinde kategorilerde değerlendirilmiştir. Kodlarla ilgili E12 kodlu katılımcı "Şimdi yardıma olan ihtiyacı mesela yardıma ihtiyacı olan bir sürü insan var. Ben Iı1... yardım ederken çocuğumun da benimle birlikte olmasına özen gösteriyorum. I11.. beni rol model olarak görüp benim yaptıklarımı görmesini, öğrenmesini bunu bir değer olarak kazanmasını istiyorum. Ona anlatıyorum işte Iı1... yaparken "İnsanlara bak onların yemeği yok. Onlara yemek alsak çok mutlu olurlar değil mi?" diye ilk önce soruyorum. Daha sonra birlikte gidip bir şeyler alıyoruz. Aldıklarımı işte kızıma verdiriyorum bak sen verdiriyorum. Çocuğa örnek olmaya çalışıyorum. Birlikte olmaya da özen gösteriyorum. Hepsini ben yapmiyorum yarısını ben yapıyorum bir kısmını da ona bırakıyorum." biçiminde belirtirken E5 kodlu katılımc "Çocuklarımın değerleri kazanması için iii örnekler gösteriyorum, etkinlikler yapıyorum, resimler yapıyoruz değerler eğitimi ile ilgili etkinlikler yapıyoruz. 11 doğruluk dürüstlükle ilgili işte eee alma verme ile ilgili kısa filmler izliyoruz, çizgi filmler izliyoruz değerler eğitimi ile ilgili bu şekilde evet." şeklinde düşüncelerini ifade etmiştir.

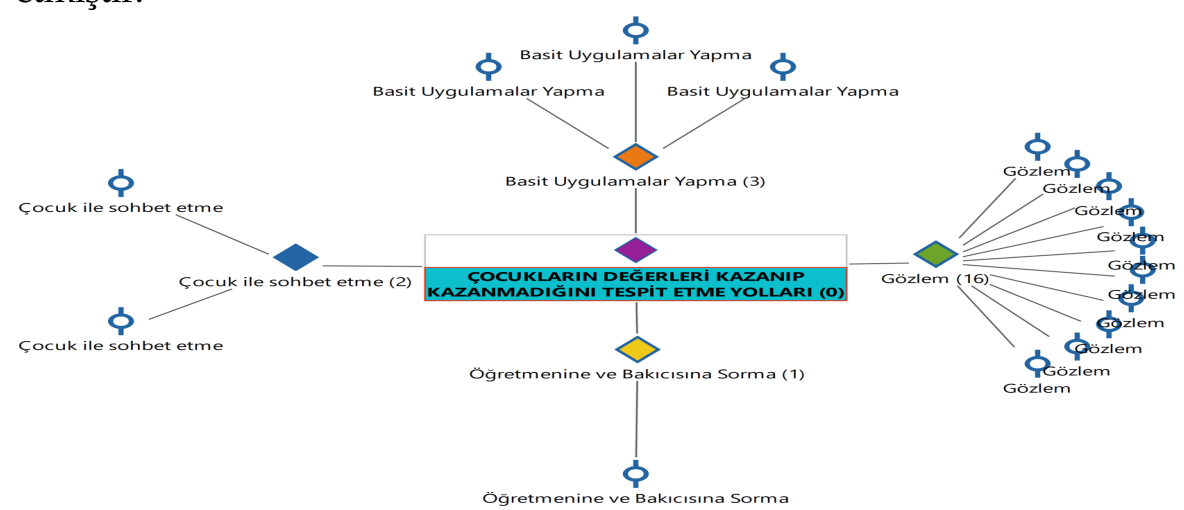

Şekil 10. Ebeveynlerin Çocukların Verilen Değerleri Kazanıp Kazanmadığını Tespit Etme Yolları

Şekil 10'da çocukların değerleri kazanıp kazanmadığını tespit etme yolları temasına ilişkin gözlem, basit uygulamalar yapma, sohbet etme ve öğretmen ile bakıcısına sorma kategorileri oluşturulmuştur. Gözlem kategorisinin oluşturulmasına kaynaklık eden örnek alıntı da ise E6 kodlu katılımc "Iımm değer ifadelerini... gözlemlerim. Iıı Öğretmenlerine soruyorum mesela ben 
varken farklı davranabiliyor çocuğum ben yokken daha farklı davranıyor. Eee Öğretmenleri ile iletişim kurarım. Eelı veya ben okula gittiğim zaman komşulara bazen bırakırım bakıcısına falan, konuşurum. Mesela geçen gün bakıcısı bana dedi ki artık dedi benim kızım da yani kendisinin de benim yaşımda kızı var bakıcımızın eeıı mesela diyor ki Begüm diyor. Buğlem geldiğinden beri paylaşmayı öğrenmeye başladı diyor. Ben de kendi kızım da fark ettim gerçekten kendi kızım da bak 3 yaşında olmasına rağmen ilk başlarda hiç paylaşmıyordu şimdi anne paylaşalım paylaşmak daha güzel değil mi diyor. Eee işte o şekilde. Gözlemliyorum yani daha çok." şeklinde ifade etmiştir.

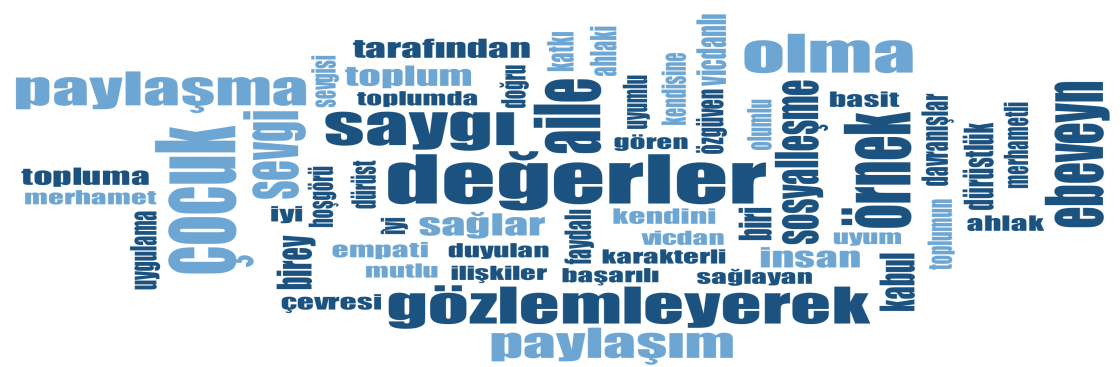

Şekil 11. Değerler Kavram Bulutu

Şekil 11'de ebeveynlerin vermiş olduğu tüm cevaplara göre oluşan kavram bulutu yer almaktadır.

\section{Tartışma ve Sonuç}

Bu bölümde çalışma sonucunda elde edilen bulgulara ilişkin genel sonuçlar alan yazın ile tartışılarak verilmiştir. Çalışmada, okul öncesi çağında çocuğu olan ebeveynlerin değerler eğitimi hakkındaki bilgi, görüş ve düşüncelerine ulaşılmaya çalışılmıştır. Araştırma sonucunda aşağıda yer alan sonuçlara ulaşılmıştır.

Okul öncesi dönemde çocuğu olan ebeveynlere göre değer kavramının "kazandırılması gereken unsurlar", "önem" ve "ahlak" içerikleri etrafında toplandığı saptanmıştır. Benzer şekilde Arıcı ve Bartan'ın (2020) yaptığı çalışmada, ebeveynlerin değer kavramını 'olumlu davranış kazandırma' şeklinde ifade ettikleri sonucuna ulaşmışlardır. Ebeveynlerin, çocuklarına kazandırmak istedikleri değerin saygı ve sevgi değerleri etrafında yoğunlaştı̆̆ı, sabır 
ve yardım severlik değerlerini ise çok az sayıda ebeveynin ifade ettiği sonucuna ulaşılmıştır. Benzer şekilde Eren (2018) yaptığı çalışmada ailelerin değer kazandırmadaki öncelikli sıralamasının, birinci sırada sevgi değeri, ikinci s1rada saygı değerinin olduğunu tespit etmiştir. Ancak paylaşma, dürüstlük, sabır ve hoşgörü değerlerinin de öncelikli sıralamada yer aldığını bulgulamıştır. Bu noktada çalışmamızla farklılaşmaktadır.

Ebeveynlerin değer eğitiminin çocuklara sağlayacağı kısa ve uzun vadeli katkılarına yönelik cevapları incelendiğinde; kısa vadede, çocukların arkadaşları tarafından benimsenmesi, arkadaşlarıyla uyum içinde olması, güven duyulan bir insan olması, toplum tarafindan kabul görmesi, karakterli bir insan olması, çocuğun özgüveninin yüksek olması, uzun vadede ise bireyin karakterinin gelişmesi, dürüst, uyumlu, merhametli, sosyal bir birey olması gibi sonuçlara ulaşılmıştır. Çalışmanın bu sonuçları MEB'in (2010) hazırlamış olduğu Değerler Eğitimi Yönergesindeki amaçların da ebeveynlerin uzun ve kısa vadeli kazanım ifadeleriyle örtüşmektedir. Yönergeye göre amaç; sorumluluk alabilen, dürüst, kendine güvenen, başkalarıyla iyi ilişkiler kuran, ülkenin kalkınmasına katkı da bulunan, ahlaki değerlere uygun davranan bireyler yetiştirmektir.

Ebeveynlere göre en önemli değerlerin "saygi, sevgi, doğruluk-dürüstlük" çerçevesinde toplandığı görülmüştür fakat bulgulara bakıldığında cömertlik değerine yalnızca bir ebeveyn tarafından vurgu yapılmıştır. Bu bağlamda değerler eğitimine ait kavramlar sayıldığında ilk akla gelenler arasında cömertlik değerinin yer almadığı yorumu yapılabilir. Arıcı ve Maden'e (2018) göre de bireyin toplumsal kişiliği doğumla birlikte oluşmaya başlar. Şekillendiği ortamlar ise başta aile ardından eğitim kurumlarıdır. Toplumun tüm değerlerini özümseyen, kendisine ve çevresine olumlu katkılarda bulunan, işbirliği yapabilen, hoşgörülü, toplumsal sorunlara duyarlı bireyler yetiştirilmesi saygı değerinin kazandırılması ile sağlanabilir. Bulgulara göre ‘özgüven, merhamet, paylaşma, empati, yardımlaşma, hoşgörünün de ebeveynler tarafından önemli değerler arasında görüldüğü sonucuna ulaşılmıştır. Aynı doğrultuda Yaka, Yalçın ve Denizli (2014) yaptığı çalışmada, ebeveynlerin öncelikli olarak "özgüven sahibi olma, kendini ifade edebilme" gibi kişisel değerlere, sonra "çalışkan olma, azimli olma" gibi akademik değerlere, daha sonra "inançlı olma, gelenek göreneklerine bağlı olma, vatansever olma, ailesine bağlı olma" gibi kültürel değerlere, son olarak "çevreye duyarlı olma, 
barışçıl olma" gibi dünyayı içine alan değerlere önem verdikleri sonucuna ulaşmışlardır.

Ebeveynlerin verdikleri cevaplara göre okul öncesi eğitim kurumlarında verilen değer eğitiminin öğretmene göre değişiklik gösterdiği ama çoğunlukla yeterli olmadığı sonucuna ulaşılmıştır. Ebeveynlerin okul öncesi öğretmenlerinden beklentilerine bakıldığında ise "ailelerin önemsediği değerlerin öğretimi" ve "rol model olma" içerikleri etrafında yoğunlaştıkları sonucuna ulaşılmıştır. Ailenin önemsediği değerlerin öğretimi kategorisinde topluma alışma, sosyalleşme, paylaşma gibi değerlerin öğretilmesi; nazik olma, sorumluluklarını yerine getirme gibi değerlerin çocuğa kazandırılması; sevgi, saygı, yardımlaşma değerlerinin pekiştirilip öğretilmesi beklentisinin olduğu sonucuna ulaşılmıştır. Ebeveynlerinin bir kısmının da "değerler eğitimine daha fazla yer verme" ve "ailelerde verilen değerlerin pekiştirilmesi" içeriklerine dair beklentide oldukları tespit edilmiştir. Elde edilen bulgular ışığında ebeveynlerin kendi önemsedikleri ve öğrettikleri değerlerin okulda pekiştirilmesi ve eksik kalan kısımların tamamlanmasına yönelik bir beklenti içinde oldukları söylenebilir.

Ebeveynlere göre, değerler eğitiminde birinci derecede sorumluluğun aileye ait olduğu sonucuna ulaşılmıştır. Demirutku'ya (2017) göre de değerlerin kazanılması açısından ilk ve en önemli yer ailedir. Çocuklar aile bireyleriyle yaşantı ve iletişim halindedirler. Bu da onların değer kavramlarını öğrenmeye başlamalarını sağlar. Bu ifadeye bakılarak ailenin çocuğa sunmuş olduğu ortamın değer öğreniminde önemli bir yere sahip olduğu söylenebilir. Benzer bir ifadeyle Yılmaz'a (2015) göre ise çocukların değerleri kazandığı ilk yer ailedir. Okul öncesi dönem çocukları yaşları ve gelişimleri itibariyle neredeyse tüm zamanlarını ailelerinin yanında geçirirler. Bu süreçte ailelerini de gözlemlerler. Bu nedenle ailelerin çocuklarına iyi birer model olmaları gerekmektedir. Morgan'e (1998) göre çocuklar anne babalarını taklit ederek kişilik özelliklerini oluşturmaya başlamaktadır. Yılmaz (2015) ve Demirutku'nun (2017), çalışmalarının sonuçları ailenin değer eğitimindeki ilk sorumlu olması bağlamında elde edilen bulgularla örtüşmektedir.

Ebeveynlere göre, çocuklara kazandırılması en zor değerin sırasıyla paylaşma, uyum ve saygı olduğu sonucuna ulaşılmıştır. Benzer şekilde Arıcı ve Bartan' ın (2020) yaptığı çalışmada paylaşma değerinin anneler tarafından kazandırılmakta zorlanıldığı sonucuna ulaşılmıştır. Buna ek olarak sorumluluk, empati, temizlik, yardımseverlik değerlerinin de kazandırılması zor değerler 
arasında oldukları sonucuna ulaşmışlardır. 3-6 yaş grubundaki çocukların egosantrik dönemde olmaları nedeniyle paylaşma değerini kazanmakta zorlandıkları için böyle bir sonuç ortaya çktığı düşünülmektedir.

Ebeveynlerin çocuklarına değerleri kazandırmak için öncelikli olarak rol model olma, çocukla değer hakkında konuşma, kitap okuma, video/çizgi film izlettirme yöntemlerinden yararlandıkları görülmektedir. Kurtdede Fidan (2009), yaptıkları çalışmada değerler eğitiminde hikâye anlatımlarının yapılması, çocuklara değerlerle alakalı sorular sorarak kendi değerlerini fark etmelerinin sağlanması, değer içerikli film ve tiyatroların önerilmesi gerektiği sonucuna ulaşmışlardır. Yavuzer'e (2019) göre ise okul öncesi dönem çocukları sosyal bir birey olmayı öğrenirken aynı zamanda detaylı olarak taklit edebilecekleri bir rol modelin varlığına ihtiyaç duyarlar. Okul öncesi dönemde çocuk, ebeveynlerinden yoğun olarak etkilenmekledir. Onların olumlu ve olumsuz özelliklerini benimseyebilir. Özdeşim kurmanın bu dönemde güçlü olması nedeniyle çocuk ebeveynlerinin; tutum, duygu, huy ve davranışlarını içselleştirerek kişiliğinin bir parçası haline getirebilir. Bu süreçte ebeveynlerinin talep ve yönelimlerine karşı duyarlı hale gelir. Ebeveynleri tarafından doğru, iyi, güzel görülenleri özümsemeye; yanlış ve kötü olanlardan ise kaçınmaya yönelik bir çaba içine girer. Kendisini yönlendirecek olan kural ve değerleri benimser (Yörükoğlu, 2016). Gürel (2014) ise çalışmasında "Bandura; çocukların ahlaki yargılarının şekillenmesinde sosyal öğrenme, sosyal pekiştireç ve model davranışlarının rolünü inceleyerek ahlaki yargı gelişimi ve değerlerin öğrenilmesini sosyal öğrenme meselesi olarak ele almıştır." şeklindeki ifadelere yer vererek modelden öğrenmenin önemine vurgu yapmıştır. Bu bağlamda ebeveynlerin değer kazandırırken rol model olmaya önem verdikleri, yazılı basılı kaynaklar ile video/filmlerden yaralandıkları ve sohbeti bir öğretim aracı olarak kullandıkları sonucuna ulaşılmıştır. "Ödül-ceza kullanımı", "pekiştirme”, "eğitim kurumuna gönderme", "çocukla birlikte yapma" ve "kitle iletişim araçların kontrollü kullandırma" da ebeveynlerin değer kazandırma sürecinde başvurdukları yollar arasındadır. Değer eğitimine ait kavramların soyut ifadeler olduğu göz önünde bulundurulduğunda bu kavramların kazandırılması için başvurulacak en kolay ve en önemli yol olan oyuna ebeveynler tarafından hiç değinilmediği görülmektedir. Buradan hareketle ebeveynlerin okul öncesi dönem çocuklarının genel özellikleri hakkında yeterli bilgiye sahip olmadıkları yorumu yapılabilir. 
Ebeveynlere göre çocuğun bir değeri kazanıp kazanmadığını tespit etmek için kullanılacak yol gözlem yapmaktır. Yuvacı, Şafak ve Şirin (2013) öğretmenlerle yaptıkları çalışmada "Çocuklara verdiğiniz değer eğitiminin çocuklarda etkili olduğunu nasıl anlıyorsunuz?" sorusuna yer vermişlerdir. Bu soruya öğretmenlerin cevapları "Bize, ailesine ve çevresinde tanımadığı insanlara karşı davranışlarındaki olumlu etkilerden anlıyorum. Davranışlarındaki değişiklerden ve o ay ailelerden gelen geri bildirimlerin olumlu olmasından" şeklindedir. Öğretmenlerin verdikleri cevaplara bakıldığında çocukların davranışlarını çeşitli durum ve ortamlarda gözlemledikleri ve buna göre bir değerlendirme yaptıkları sonucu çıkarılabilir. Bu durum çalışma sonucunda elde edilen bulgularla örtüşmektedir. Ebeveynlerin neredeyse tamamı gözlem yapmada hemfikirken buna ek olarak basit uygulamalar yapma, çocuk ile sohbet etme, öğretmen ve bakıcısına sorma gibi yollara da başvurdukları sonucuna ulaşılmıştır.

\section{Öneriler}

- Süreç boyunca incelenen alan yazın çalışmalarında ve ebeveynlerle yapılan görüşmeler sırasında dikkat çeken unsurun ebeveynlerin değer kavramı ve değerler eğitimi hakkında yeterli bir bilgiye sahip olmadıklarıdır. Bu sonuçlar doğrultusunda, değerlerin neler olduğuna dair ebeveynlere yönelik bilgilendirici çalışmaların yapılması önerilmektedir. Değer öğretimine anne babalardan başlamak sorunun kaynağına inmek için bir çözüm yolu olabilir.

- Ailelerin çocuklarına değer kazandırma sürecinde rol model olurken sağlıklı bir iletişim ortamını oluşturmaları, çocuğun düşünce ve ifadelerine saygı göstermeleri önerilmektedir.

- Okul aile işbirliğinin sağlanması, velilerin değerler eğitimi hakkındaki sorun ya da önerilerini okul öncesi öğretmenleriyle açkça paylaşabilmeleri, varsa beklentilerini iletebilmeleri de değerler eğitimi sürecinin başarilı tamamlanmasını sağlayabilir.

- Öğretmenlerin değerler eğitimini verirken ebeveynlerin görüşlerini ve beklentilerini dikkate alması önerilmektedir.

- Araştırmacılara yönelik ise ebeveynlerin değerler eğitimi konusunda görüşlerinin karma yöntem kullanılarak incelenmesi ve daha fazla katılımcı ile çalışma yapılması önerilmektedir. 
EXTENDED ABSTRACT

\title{
Examination of the Views of the Parents that Preschool Children on Values Education
}

\author{
Ensar Y1ld1z - Hasibe Elibol - Merve Ada \\ Sivas Cumhuriyet University
}

The goal of values education is to protect the society, particularly the individual, from unwanted bad morals, to ensure the continuity of the society, to foster the development of individuals' personalities in all aspects by revealing their innate good sides, and to ensure that they become individuals with good morals approved by the society (Aydın and Akyol, 2012). In this respect, values education aims to impart many social and individual values such as responsibility, respect, benevolence, patriotism, friendship, justice to people (Altan, 2011).

The fact that the family is the first social group a child encounters when he/she is born has once again revealed how important the place of the family is in values education (Kir, 2010). Since the family is the place where the child first encounters social values and begins to receive values education, the family plays a very important role in training children in accordance with the value judgments of the society (Çağdaş and Seçer, 2002). Children learn the social values, rules and culture that shape their personalities by interacting with the individuals in the family, especially by observing their parents and taking them as role models to themselves (Balat and Balaban, 2011; Günindi, 2010).

Although families play an important role in values education, when the literature is reviewed, it is seen that there is a limited number of studies on values education within the family. In this connection, the current study is believed to help fill this void. In the current study, it is aimed to examine the opinions of parents who have children in the preschool period about values education. To this end, answers to the following questions were sought.

1. What does the concept of value mean to parents?

2. What are the most important values according to parents? 
3. Who has the primary responsibility in values education according to parents?

4. What are the values parents want to impart to their children?

5. What are the contributions of values education to children according to parents?

6. What are the ways followed by parents to impart values to their children?

7. What are the values parents experience difficulty in imparting to their children?

8. What are the means used by parents to determine whether their children have acquired values?

9. What are parents' expectations from preschool teachers in terms of the inculcation of values in children?

10. What are parents' opinions about the adequacy of values education activities conducted in preschool institutions?

The current study employed the case study design, one of the qualitative research methods. This is a method allowing the researcher to conduct an in-depth investigation of a case or an event on the basis of how and why questions (Yıldırım and Şimşek, 2016). In the selection of the study participants, the criterion sampling method, one of the purposive sampling methods, was used.

The criterion sampling selection requires meeting a series of pre-determined criteria (Yıldırım and Şimşek, 2016). The criteria adopted in the selection of the participants in the current study were having a child aged 36 years old and attending a preschool institution. In Table 1, demographic information about the participating parents is presented. In the collection of the study data, a "Personal Information Form" and a semi-structured interview form developed by the researchers to elicit the parents' opinions about values education were used. The collected data were analyzed by using two of the qualitative research methods, descriptive and content analyses, in MAXQDA Pro2018.2.5 software program. Descriptive analysis is used in cases where the theoretical structure of the study is clear (Y1ldırım and Şimşek, 2016). Moreover, for the construction of codes and categories during the analysis of the written documents, the content analysis technique proposed by Mayring (2004) was used. In this context, first, the collected sound recordings were transcribed in order to perform inductive 
categorisation and then codes were determined with Maxqda Pro2018.2.5 software program and themes were constructed through visual maps by combining upper categories developed according to the problem statement. Direct quotations from participants are also presented in relation to the model constructed in line with the descriptive analysis.

Within the theme of parents' expectations from preschool teachers, the following categories were formed; "Teaching the values considered to be important by families", "Being a good role model", "Allocating more space to values education" and "Reinforcing the values given within the family". Within the theme of the people having the primary responsibility in values education, only the following category was found; "Family". Within the theme of the adequacy of values education activities conducted in preschool institutions, the following categories were found; "Adequacy changes from teacher to teacher", "Moderately adequate", "Inadequate".

According to the parents having children in the preschool period, the concept of value can be handled around the contents of "elements to be imparted", "importance" and "morals". The parents are of the opinion that the most important values to be imparted to their children are "respect, love, honesty" yet "benevolence" was emphasized by only one parent. In light of the responses given by the parents, it was concluded that values education given in preschool institutions changes from teacher to teacher yet it is largely inadequate. The parents think that the values most difficult to impart to children are sharing, adaptation and respect.

\section{Kaynakça/References}

Abacı, E. (2018). Behiç Ak'ın çocuk kitaplarının değerler eğitimi açısından incelenmesi. (Yayınlanmamış Yüksek Lisans Tezi). Bülent Ecevit Üniversitesi Sosyal Bilimler Enstitüsü, Zonguldak.

Ada, E. (2016). Erken çocukluk döneminde yaratıcı drama yönteminin değerler eğitimine olan etkisinin incelenmesi. (Yayınlanmamış Yüksek Lisans Tezi). Kastamonu Üniversitesi Eğitim Bilimleri Enstitüsü, Kastamonu.

Altan, M. Z. (2011). Çoklu zekâ kuramı ve değerler eğitimi. Pegem Eğitim ve Öğretim Dergisi, 1(4), 54-57. 
Arıcı, D. ve Bartan, M. (2020). Çocuğu okul öncesi eğitime devam eden annelerin çocuklarına değer edindirme sürecine yönelik görüşleri. Ahi Evran Üniversitesi Sosyal Bilimler Enstitüsü Dergisi (AEÜSBED), 6(1), 279294.

Arıc1, İ. ve Maden, K. (2018). İlköğretim Din Kültürü ve Ahlak Bilgisi öğretim programında sayg1 değeri. Atatürk Üniversitesi Sosyal Bilimler Enstitüsü Dergisi, 22(1), 237-256.

Avcı, N. (2007). Üniversite gençliğinin bireysel ve toplumsal değerlere ilgi ve bakışı. R. Kaymakcan. vd. (Ed.), Değerler ve Ĕ̆itimi içinde (s.819-851) İstanbul: Dem Yayınları.

Aydın, M. Z. ve Akyol, Ş. (2012). Okulda değerler eğitimi. Ankara: Nobel Yayıncilik.

Balat, G. U. ve Balaban, A. (2011). Okul öncesi dönemde değerler eğitimi etkinlikleri. Ankara: Kök Yayıncilık.

Corbetta, P. (2003). Social research: Theory, methods and techniques. London: Sage Publications.

Çağdaş, A. ve Seçer, Z. (2002). Çocuk ve ergende sosyal ve ahlak gelişimi. Ankara: Nobel.

Demiriz, S., Karadağ, A. ve Ulutaş. İ. (2003). Okul öncesi eğitim kurumlarında eğitim ortamı ve donanım. Ankara: Anı Yayıncılık.

Demirutku, K. (2017). Değerlerin edinilmesinde ailenin rolü. Ankara: Aile ve Sosyal Politikalar Bakanlığı.

Dilmaç, B. (2002). İnsanca değerler eğitimi. Ankara: Nobel Yayın Dağıtım.

Dinç, B. (2011). Okulöncesi dönemde değerler eğitiminin yeri ve önemi. A. Arıkan (Ed.), Okulöncesi dönemde değerler eğitimi içinde (s.149-164). Eskişehir: Anadolu Üniversitesi Web-Ofset Tesisi.

Ekşi, H. (2003). Temel insani değerlerin kazandırılmasında bir yaklaşım: Karakter eğitimi programları. Değerler Ĕ̆itimi Dergisi, 1(1), 79-96.

Greenberg, M. T., Weissberg, R. P., Zins, J. E., Fredericks, L., Resnik. H. and Ellias, M. J. (2003). Enhancing school-based prevention and youth development through coordinated social, emotional and academic learning. American Psychologist, 58(6/7), 466-474.

Güder, S. (2015). İlkokul döneminde değerlerin kapsamı. Okul öncesi ve ilkokul döneminde değerler eğitimi. Ankara: Eğiten Kitap.

Gümüş, S. (2017). Değerler eğitimi bağlamında Aytül Akal'ın çocuk romanlarının analizi (Yayınlanmamış Yüksek Lisans Tezi). Marmara Üniversitesi Eğitim Bilimleri Enstitüsü, İstanbul. 
Günindi, Y. (2010). Anasınıfina devam eden altı yaş çocuklarına uygulanan sosyal uyum beceri eğitimi programının çocukların sosyal uyum becerilerinin gelişimine etkisi .(Yayınlanmamış Yüksek Lisans Tezi). Gazi Üniversitesi Eğitim Bilimleri Enstitüsü, Ankara.

Gürel, R. (2014). Sosyal pekiştireçlerin ve model davranışlarının çocukların ahlaki yargılarının şekillenmesindeki etkisi (Bandura örneği). Değerler Ĕ̆itimi Dergisi, 12(28), 101-119.

Güven, G. ve Azkeskin, K. F. (2010) . Erken çocukluk gelişimi ve okul öncesi eğitim. D. İbrahim Hakkı (Ed.), Erken çocukluk eğitimi içinde (s.2-50). Ankara: Pegem Akademi.

Karaömerlioğlu, L. (2010). Okul öncesi eğitimde doğaçlama. (Yayımlanmamış Yüksek Lisans Tezi). Çukurova Üniversitesi Sosyal Bilimler Üniversitesi, Adana.

Kır, İ. (2010). Eğitimin toplumsal temelleri. F.Töremen (Ed.), Eğitim bilimine giriş. İstanbul: İdeal Kültür Yayınları.

Kurtdede Fidan, N. (2009). Öğretmen adaylarının değer öğretimine ilişkin görüşleri. Kuramsal Eğitimbilim, 2(2), 1-18.

Lincoln, Y. S., and Guba, E. G. (1986). But is it rigorous? Trustworthiness and authenticity in naturalistic evaluation. New Directions For Evaluation, $30,73-84$.

Mayring, P. (2004). Qualitative content analysis. A Companion to Qualitative Research, 1(2004), 159-176.

Merleau-Ponty, M. (2013). The phenomenology of perception. London: Routledge. MEB. (2010). 08/09/2010 tarihli ve B.08.0.TTK.0.72.02.00-6312 (2010/53) sayılı Genelge.

Morgan, C. (1998). Psikolojize giriş. (H. Arıcı ve Diğerleri, Çev.). Ankara: Hacettepe Üniversitesi Psikoloji.

Samur, A. Ö. (2011). Değerler eğitimi programının 6 yaş çocuklarının sosyal ve duygusal gelişimlerine etkisi. (Yayınlanmamış Doktora Tezi). Selçuk Üniversitesi Sosyal Bilimler Enstitüsü, Konya.

Sapsağlam, Ö. (2016). Okul öncesi eğitim programlarında yer alan hedeflerin değerler eğitimi açısından incelenmesi. International Periodical for the Languages, Literature and History of Turkish or Turkic, 11(9), 683-700.

Şahin, F. (2010) . 0-6 yaş çocukların temel gelişimsel özellikleri: Fiziksel ve sosyal duygusal gelişim. D. İbrahim Hakkı (Ed.), Erken çocukluk e ğitimi içinde (s.170-206). Ankara: Pegem Akademi. 
Şahin, F. (2005). Çocuğun gelişimi ve eğitiminde babanın rolü. M. Sevinç (Ed.), Erken çocuklukta gelişim ve eğitimde yeni yaklaşımlar. İstanbul: Morpa Kültür Yayınları.

Tanrıverdi, Ö. (2012). Yaratıcı drama ile verilen eğitimin okul öncesi öğrencilerin çeore farkındalı̆̆ına etkisi. (Yayınlanmamış Yüksek Lisans Tezi). Muğla Sitkı Koçman Üniversitesi Eğitim Bilimleri Enstitüsü, Muğla.

Türk, İ. (2009). Değerler eğitiminde saygı.(Yayınlanmamış Yüksek Lisans Tezi). Gaziosmanpaşa Üniversitesi Sosyal Bilimler Enstitüsü, Tokat.

Türkkahraman, M. (2003). Social values and value education. Procedia - Social and Behavioral Sciences, 116(2014), 633-638.

Ulusoy, K. ve Arslan, A. (2014). Değerli bir kavram olarak “değer ve değerler eğitimi". R. Turan ve K. Ulusoy (Eds.), Farklı yönleriyle değerler eğitimi içinde (s.2-14). Ankara: Pegem Akademi.

Veugelers, W., and Vedder P. (2003). Values in teaching. Teachers and Teaching: Theory and Practice, 9(4), 377-389.

Yaman, E. (2012). Değerler eğitimi. Ankara: Akçă̆ Kitabevi.

Yavuzer, H. (2019). Çocuk psikolojisi. İstanbul: Remzi Kitapevi.

Yılmaz, E. (2015). Her şey ailede başlar: Uygulamalı aile değer eğitimi kitabı. 15.11.2020 tarihinde http://www.medeniyetokulu.com/uploads/2015/10/05/ebrosur-df9e4bb2.pdf adresinden alınmıştır.

Yıldırım, A. ve Şimşek, H. (2016). Sosyal bilimlerde nitel araştırma yöntemleri. Ankara: Seçkin Yayıncılık.

Yörükoğlu, A. (2016). Çocuk ruh sağhlğı. İstanbul: Özgür Yayınları.

Yuvacı, Z., Şafak, M. ve Şirin, N. (2013). Okul öncesi çocuklarına değer eğitimi verirken davranış geliştirme merkezli öğrenme yöntemi uygulayan öğretmenlerin görüşleri. Middle Eastern \& African Journal of Educatinal Research, 5, 112-135.

\section{Kaynakça Bilgisi / Citation Information}

Yıldız, E., Elibol, H., ve Ada, M. (2021). Okul öncesi eğitim çağında çocuğu olan ebeveynlerin değerler eğitimi hakkındaki görüşlerinin incelenmesi. OPUS-Uluslararası Toplum Araştırmaları Dergisi, 18(40), 2317-2344. DOI:10.26466//opus.864098. 